\title{
The Effect of the Aging Process on Selected Properties of Polypropylene Modified by Natural Fillers
}

\author{
Bronisław Samujło ${ }^{1}$ \\ 1 Department of Technology and Polymer Processing, Lublin University of Technology, ul. Nadbystrzycka 36, \\ 20-618 Lublin, Poland \\ e-mail: b.samujlo@pollub.pl
}

\begin{abstract}
The purpose of the research was to determine the aging-induced changes in the selected mechanical properties and flammability of polypropylene modified with natural fillers (sunflower husk, wheat bran, pine sawdust and talc). The fillers were introduced into polypropylene in a mechanical mixing process (weight content $20 \%$ ). The samples were obtained with the use of an Allrounder 320 C500-170 laboratory injection molding machine. The aging process under artificial sample conditions was carried out in the laboratory chamber (aging time of 0, 60, 120, 240,360 hours). The tests of the mechanical properties included the measurements of hardness, impact strength and tensile strength. The flammability tests were carried out with a vertical and horizontal alignment of the sample according to the PN-EN 60695-11-10 standard. As a result of the research, a significant impact of the introduction of natural fillers in the form of sunflower husks, wheat bran and pine sawdust on the selected properties of polypropylene was demonstrated. A large decrease in the impact toughness, a relatively small decrease in the short-term tensile strength as well as an increase in the elastic modulus and stress at rupture caused by the introduction of the natural fillers mentioned, were found. A beneficial effect was the relatively small impact of aging on the mechanical properties and flammability of the modified polypropylene fillers.
\end{abstract}

Keywords: polypropylene, natural fillers, aging effect, mechanical properties, flammability

\section{INTRODUCTION}

A widespread use of polymer plastics in the second half of the twentieth century resulted in a partial or almost total displacement of traditional materials from many applications. This applied to the construction materials in machine designing, means of transport, building engineering, electronics and electrotechnics, household items but mainly in packaging. Synthetic polymers and plastics based on them, as well as polymer composites have many advantages. For instance, they characterized by high resistance to aging and decomposition, as well as biological properties $[5,6]$. Large amounts of generated waste, initially deposited in waste dumps, are currently undergoing various forms of recycling of materials, raw materials and energy. However, a significant part of the waste is still deposited on landfills and outside them, the decomposition of which can last from several to even thousands of years. Storage is the least beneficial method for the disposal of plastic waste, because it creates the ecological risks associated with long exclusion of ground from use, the possibility of soil and groundwater contamination, water contamination in the event of flooding, and at the same time is uneconomical and socially unacceptable. The indirect products of plastic degradation also include accumulation in living organisms, threatening their health and life $[1,5,6]$.

Currently, the ecological, healthy for the environment lifestyle is increasingly promoted, derived from the English words "Reduce, Reuse, Recycle, Repair". In 2018, the EU strategy on plastics was published, in May a draft directive was presented in the field of single-use plastic products (so-called Single Use Plastic) and a 
package of directives on the circular economy was implemented. These regulations are intended to improve the use of plastics, inter alia, by improving the operation of the ROP system, i.e. extended producer responsibility; improvement of the products already at the design stage; creating markets for the reuse of plastics and recycled materials; significant reduction in the plastic consumption, and even the elimination of some disposable plastic items from the market and the use of biodegradable materials. This causes a steady increase in the interest in the degraded and biodegradable plastics and composites. Traditional polymer composites are often being replaced by biocomposites in an increasing number of applications. The biocomposites with plant fillers are used in various sectors of the economy, primarily in the automotive industry and building engineering $[1,6,7,11]$.

The composites with natural fibers such as kenaf, sisal, jute, flax, hemp, wood flour, bamboo, cotton and coconut fibers are most often researched $[1-3,6,7,11]$. Attempts are also being made to obtain cheap biocomposites partially degraded on the basis of polyethylene and waste from the food industry in the form of sunflower husks, nut shells, pistachios, and bran $[2,8,9$, 11]. The fibers found in this type of fillers mainly consist of organic compounds (cellulose, hemicellulose and lignin) which limits the maximum temperature and processing to about $200^{\circ} \mathrm{C}$. This results in the choice of thermoplastic polymer composites such as polyethylene, polyvinyl chloride, polystyrene and polypropylene, which are also characterized by low viscosity at high melt flow index values. A frequent adverse effect of introducing this type of natural filler is the deterioration of the mechanical properties and flammability $[2-4,7,8,10]$. As part of wider research on the processing processes and properties of composites with natural fillers, the injection tests were carried out as well as the mechanical properties and flammability of the biocomposites based on polypropylene with natural fillers in the form of pine sawdust, sunflower husk and wheat bran were examined.

\section{METHODOLOGY OF RESEARCH}

The purpose of the research was to determine the aging-induced changes in the selected mechanical properties and flammability of polypropylene modified with natural fillers. Moplen EP440G (Bassel Orlen Polyolefins Sp. z o.o.) with a MFR flow rate of $1.3 \mathrm{~g} / 10 \mathrm{~min}\left(230^{\circ} \mathrm{C} ; 2.16 \mathrm{~kg}\right)$ was used as the base material, characterized by high impact strength and used in extrusion processes, mainly of thin-walled products and injection molding. The natural fillers introduced into PP were the production waste from the food processing industry in the form of sunflower husk (hereinafter referred to as B) and wheat bran (C), waste from wood treatment in the form of pine sawdust (D) and, for comparison, a standard filler in the form of talc (E) (mesch 325, Techland Lab). The fillers, after drying for 24 hours at $40^{\circ} \mathrm{C}$, were introduced into polypropylene in a mechanical mixing process, their weight content was determined on the basis of the data contained in the available literature at $20 \%$. At this content of fillers, a relatively small reduction in the mechanical properties as well as the resistance to ignition and combustion of polypropylene was expected, while obtaining favorable performance characteristics such as smell and appearance similar to natural materials. The samples from unmodified polypropylene marked A were also made for the comparison purposes.

The samples in the form of classic dumbbells for strength tests (Fig. 1) were obtained with the use of an Allrounder 320 C500-170 laboratory injection molding machine, with constant injection process conditions selected on the basis of a literature analysis, which included the temperature in individual heating zones of the $\mathrm{T}_{1-4}$ injection molding system, amounting to $160,170,180$ and $180^{\circ} \mathrm{C}$, nozzle temperature $\mathrm{T}_{\mathrm{z}}=220^{\circ} \mathrm{C}$, temperature in the charge area $\mathrm{Tz}=30^{\circ} \mathrm{C}$, injection pressure $\mathrm{p}_{\mathrm{w}}=90 \mathrm{MPa}$, temperature of the injection mold thermostat $\mathrm{T}_{\mathrm{f}}=23^{\circ} \mathrm{C}$, cooling time of the mold cavity $t_{c h}=20 \mathrm{~s}$, total cycle time of the injection process $t_{c}=34 \mathrm{sec}$.

The aging process under artificial sample conditions was carried out in the POL-EKO laboratory chamber model SLW 115 TOP + . The chamber had forced air circulation at a volume of $115 \mathrm{dm}^{3}$. The tests of the mechanical properties included the measurements of hardness, impact strength and tensile strength. The hardness tests were carried out according to the recommendations of the PN-EN ISO 868: 2005 standard using a Shore hardness tester, AFFRRI ART model. 13 with a test head according to the D scale. The impact tests were performed using a Charpy hammer from Cometech Testing Machines type 


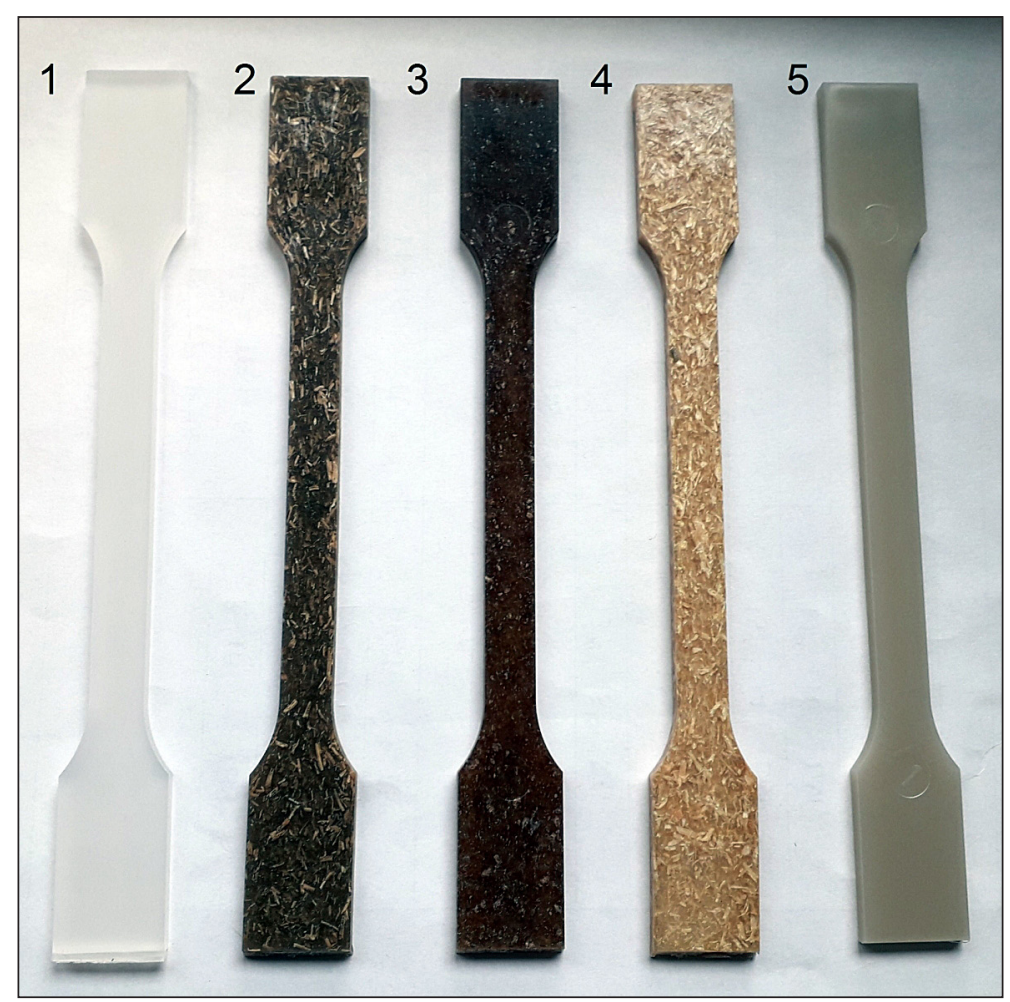

Fig. 1. The view of samples for testing: 1- A, $2-B, 3-C, 4-D, 5-E$ (designation in text)

639F (Fig. 2a) according to the recommendations of PN-EN ISO 179-2: 2001. The samples used during the tests were not notched. The strength tests were carried out in a static tensile test according to the recommendations of PN-EN ISO 527: 1998 using a ZWICK / ROELL Z010 testing machine with a head with a maximum tensile force of $10 \mathrm{kN}$. The flammability tests in the presence of an ignition source were carried out with a vertical and horizontal alignment of the sample, according to PN-EN 60695-11-10 standard using a universal test setup for testing the flammability of plastics provided by KTiPTP Lublin University of Technology (Fig. 2b). The ignition source was a $50 \mathrm{~W}$ propane gas burner. After mounting and igniting the sample, the burning time of the sample and the length of the burnt part were measured. a)

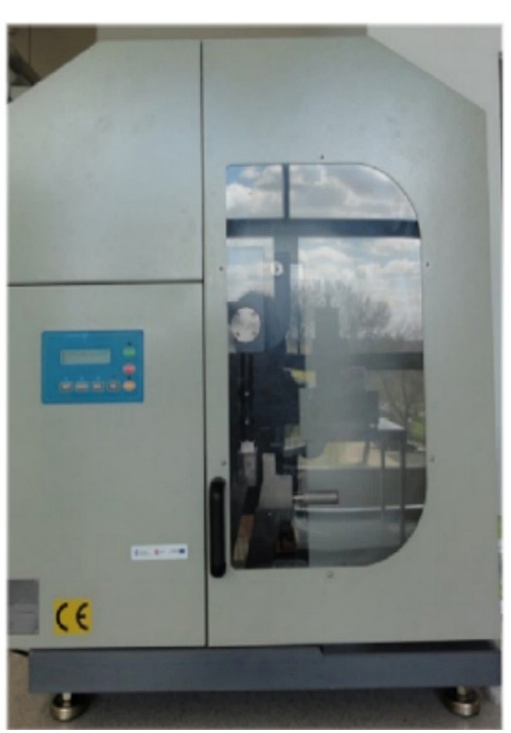

b)

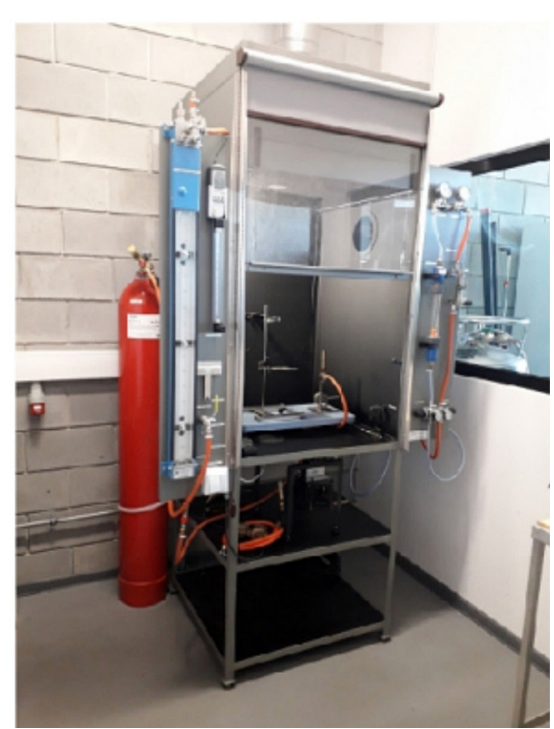

Fig. 2. General view of test stands: a) Charpy's hammer from Cometech Testing Machines type 639F, b) universal test stand for flammability testing of plastics 
The variable factors were the type of filler (none $-\mathrm{A}$, sunflower husk $-\mathrm{B}$, wheat bran $-\mathrm{C}$, pine sawdust $-\mathrm{D}$, talc $-\mathrm{E}$ ) and the aging time $\mathrm{t}_{\mathrm{s}}$ of $0,60,120,240,360$ hours. The main constant factors were the type of base material, the stretching speed during the strength tests of $50 \mathrm{~mm} / \mathrm{min}$, the temperature in the aging chamber $\mathrm{T}_{\mathrm{s}}=60^{\circ} \mathrm{C}$, the changes in electric voltage from 219 to $241 \mathrm{~V}$, relative air humidity from 45 to $55 \%$, temperature ambient from 20 to $24^{\circ} \mathrm{C}$ were assumed as the disturbing factors. However, it is estimated that the influence of the disturbing factors was minimal and can be neglected. The list of the tested factors directly includes Shore hardness $\mathrm{H}\left[{ }^{\circ} \mathrm{Sh}\right]$, force $\mathrm{F}[\mathrm{N}]$ and absolute elongation during tensile strength test $\Delta 1$ [mm], [1 pendulum swing angle $\phi$ $\left[{ }^{\circ}\right]$ and energy used for the dynamic destruction of the sample during the test impact strength $\mathrm{A}[\mathrm{J}]$ , length of the burnt sample section $1_{\mathrm{sp}}[\mathrm{mm}]$ and time $t_{\mathrm{sp}}[\mathrm{s}]$ of combustion during the flammability test. Immediate tensile strength $\mathrm{R}_{\mathrm{m}}[\mathrm{MPa}]$, modulus of elasticity at tension $\mathrm{E}[\mathrm{MPa}]$, relative elongation at maximum stress $\varepsilon_{\mathrm{m}}[\%]$, impact strength $\mathrm{a}_{\mathrm{c}}\left[\mathrm{kJ} / \mathrm{m}^{2}\right]$, linear combustion speed $\mathrm{v}_{\mathrm{sp}}[\mathrm{m} / \mathrm{s}]$ and class flammability of the tested materials were determined.

The samples to be tested were placed in the aging chamber, and after each determined aging time they were subjected to the program of tests for the mechanical properties. The flammability tests of the tested materials were carried out immediately after the samples were produced and after 360 hours of aging.

\section{RESULTS}

As a result of the tests carried out on the modified polypropylene samples, the data (Table 1) enabling the determination of the dependence of hardness on the type of filler and aging time were obtained. No statistically significant dependence of hardness on the type of filler used was obtained. The highest hardness values were obtained for the PP samples filled with talc (curve E), which is in line with expectations, but only slightly lower results were obtained for the unmodified PP (curve A). Slightly lower hardness values were obtained for the PP samples containing wheat bran (C), pine sawdust (D) and sunflower husk (B). No statistically significant dependence of the hardness of the tested samples on the aging time was obtained; however, some regularities were observed. In the case of the talc-modified polypropylene there was a small but noticeable, almost $3 \%$ decrease in hardness with aging. A similar trend was observed in the case of the bran modified PP (curve C). There was also a slight increase in the hardness of the samples made of PP modified with pine sawdust (curve D) and sunflower husk (curve B) after 360 hours of aging. No statistically significant changes in the hardness of the unmodified PP were observed, but in this case there was also a decreasing tendency.

The impact tests of the modified PP samples were also carried out and their results are summarized in Figure 3. It was found that the impact strength of polypropylene is influenced by the introduction of fillers and, to a small extent, their type and aging time. The introduction of both the natural fillers and talc significantly reduced the impact strength compared to the unmodified PP, which is in accordance with the expectations. The highest decrease in the impact toughness was observed after the introduction of pine sawdust and sunflower husks, to nearly $7 \%$ of the initial size, slightly smaller in the case of introduced bran $(13 \%)$ and talc $(19 \%)$. The impact strength of the polypropylene without filler content dropped after 360 hours of aging from 122.4 to $110.08 \mathrm{~kJ} / \mathrm{m}^{2}$, which is a decrease of $10 \%$ from the initial value. The impact strength of the samples with the addition of talc after 360 hours of aging decreased by nearly $13 \%$, but no statistically significant

Table 1. Shore hardness test results (designation in text)

\begin{tabular}{|c|c|c|c|c|c|}
\hline \multirow{2}{*}{ Type of filler } & \multicolumn{5}{|c|}{ Aging time $t_{s}, h$} \\
\cline { 2 - 6 } & 0 & 60 & 120 & \multicolumn{2}{c|}{240} \\
\cline { 2 - 6 } & \multicolumn{5}{|c|}{ Shore D hardness, ${ }^{\circ}$ Sh } \\
\hline A & 66.2 & 65.5 & 65.3 & 64.7 & 64.2 \\
\hline B & 63.1 & 63.2 & 63.5 & 62.9 & 64.1 \\
\hline C & 65.2 & 64.6 & 64.1 & 65.5 & 62.7 \\
\hline D & 64.5 & 64.4 & 64.9 & 66.1 \\
\hline E & 66.5 & 66.2 & 66.5 & 65.9 \\
\hline
\end{tabular}




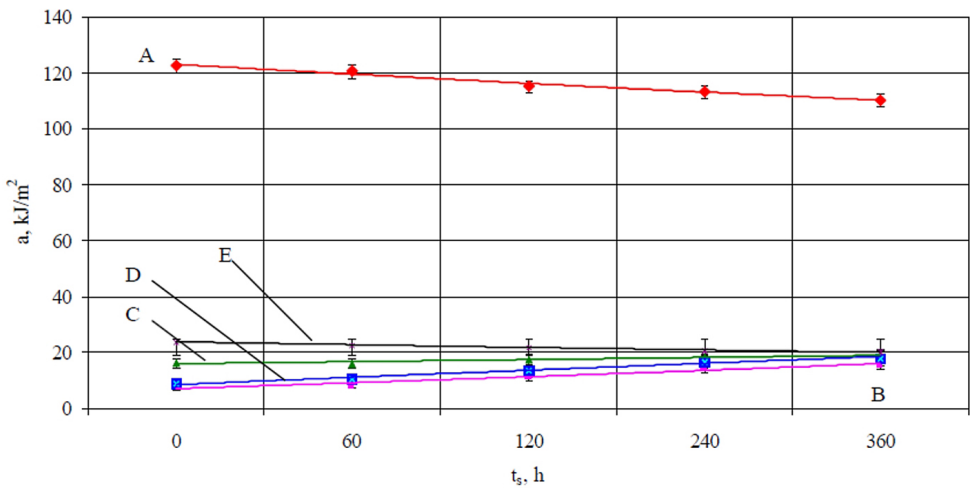

Fig. 3. Graph of the impact strenght $a_{k}$ on the filler type and aging time $t_{s}$ (designation in text)

relationship was obtained. The aging of polypropylene with the addition of natural fillers resulted in a small (16.5\%) increase in the impact strength for wheat bran, while the addition of sunflower husk and pine sawdust unexpectedly resulted in a nearly double increase in impact strength, by 107.9 and $105.7 \%$, respectively.

The tensile strength tests made it possible to determine the relationship of the selected polypropylene strength parameters such as immediate tensile strength $R_{m}$ (Fig. 4), modulus of longitudinal elasticity at tension E (Fig. 5), stress at rupture $R_{u}$ (Fig. 6) and elongation at maximum tensile stress $\varepsilon_{\mathrm{m}}$ (Fig. 7) depending on the type of filler and aging time.

It was assumed that the immediate tensile strength $\mathrm{R}_{\mathrm{m}}$ of polypropylene is influenced by the type of filler and to a lesser extent the aging time (Fig. 4). The introduction of both the natural fillers and talc reduced the $R_{m}$ value relative to the unmodified PP, which is in line with expectations. The strength of the talc-modified PP decreased the least, from nearly $3 \%$ before aging to $7 \%$ after 360 hours of aging under artificial conditions (curve E). To a slightly greater extent, the strength was reduced by the introduction of pine

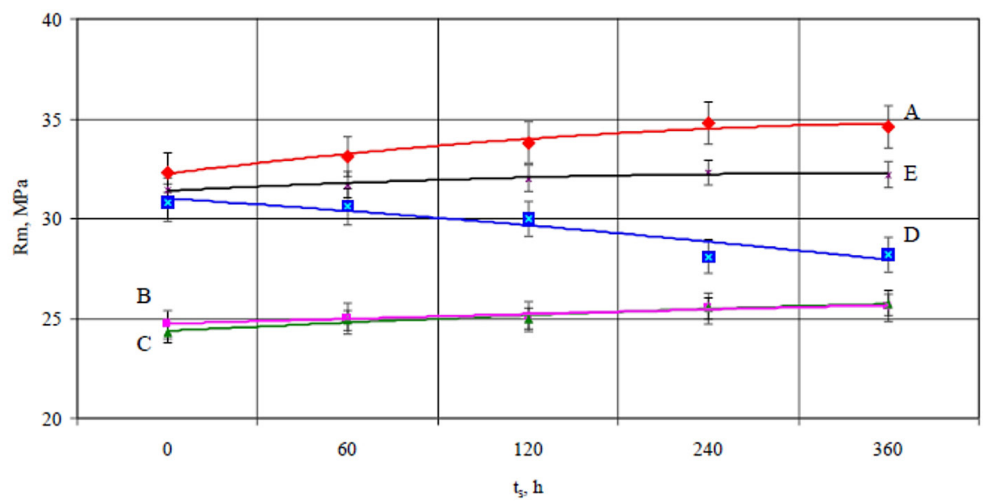

Fig. 4. Graph of the tensile strenght $\mathrm{Rm}$ on the filler type and aging time $\mathrm{t}_{\mathrm{s}}$ (designation in text)

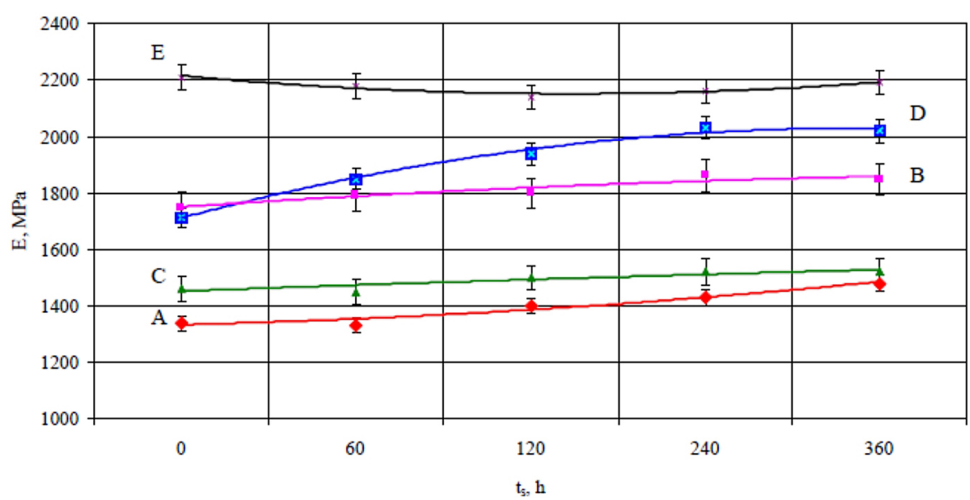

Fig. 5. Graph of the longitudinal modulus $E$ on the filler type and aging time $t_{s}$ (designation in text) 


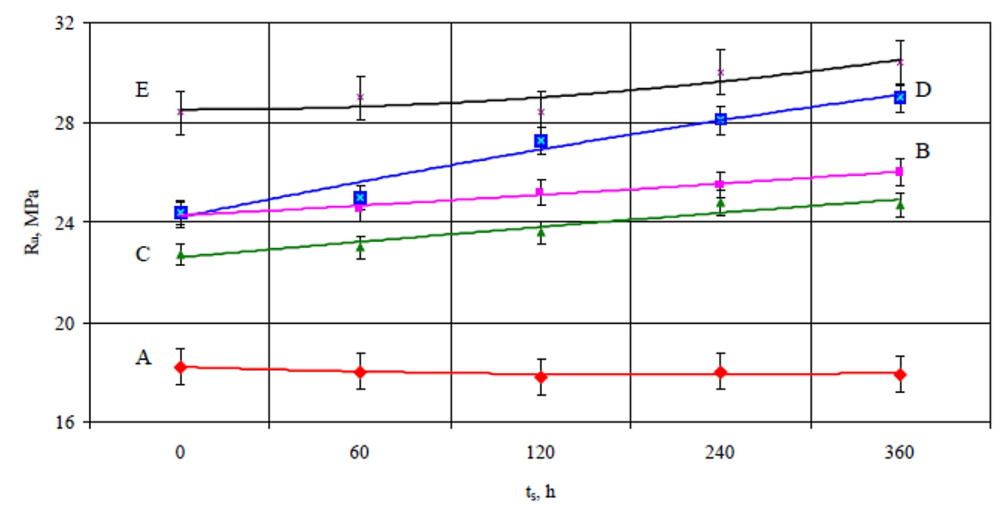

Fig. 6. Graph of the stress at rupture $R_{u}$ on the filler type and aging time $t_{s}$ (designation in text)

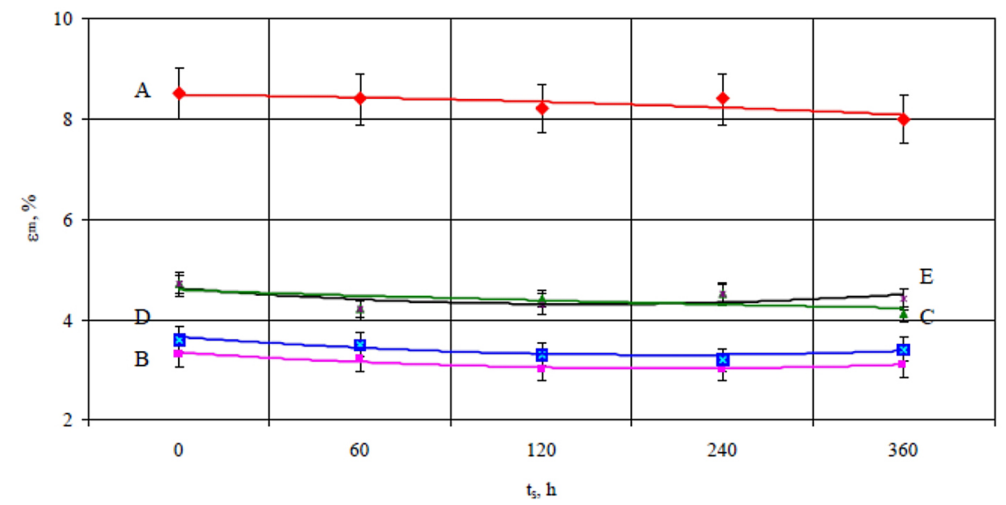

Fig. 7. Graph of the elongation at rupture $\varepsilon_{\mathrm{r}}$ on the filler type and aging time $\mathrm{t}_{\mathrm{s}}$ (designation in text)

sawdust (curve D), by 4.5 to $18.5 \%$, respectively. The introduction of wheat bran and sunflower husk (B and C curves), by 20 to $26 \%$, respectively, in relation to the strength of the unmodified PP had a significant impact on the decrease in the $R_{m}$ value. As a result of the aging process, the $R_{m}$ values increased by almost $7 \%$ in the case of the unmodified PP, slightly (3.5-5.7\%) in the case of the PP with sunflower husk, bran and talc, while they visibly decreased by $8.4 \%$ introduction to PP of pine sawdust.

The introduction of all fillers into the PP range tested resulted in the expected increase in the longitudinal modulus E (Fig. 5). This was most observed in talc, where the $\mathrm{E}$ value increased from $1340 \mathrm{MPa}$ obtained for pure PP to $2210 \mathrm{MPa}$. To a slightly lesser extent, this effect applied to sunflower and sawdust (increase by $28-30 \%$ compared to the value for pure PP) as well as bran, which caused only a $9 \%$ increase in the value of E. The aging process did not cause statistically significant changes in the elastic modulus of the PP modified by the applied fillers, except pine sawdust (curve D), where there was a nearly $18 \%$ increase in its value. A slight increase in the $\mathrm{E}$ value was also observed for pure PP, from 1340 to $1480 \mathrm{MPa}$.

The stress at rupture $\mathrm{R}_{\mathrm{u}}$ of the tested modified PP samples increased after the introduction of fillers (Fig. 6). The largest increase in this value was observed in the sample containing talc from 18.2 to $28.4 \mathrm{MPa}$, which corresponds to an increase of $\mathrm{R}_{\mathrm{u}}$ by nearly $56 \%$ compared to unmodified PP. The introduction of the remaining fillers resulted in a $25-34 \%$ increase in stress at rupture, with these differences increasing with aging. The aging process did not cause the $R_{u}$ changes in the case of unmodified PP, a relatively small (6-8\%) increase in its value in the case of the samples containing talc (E), sunflower husk (B) and pine bran (C). Only when sawdust of pine (D) was introduced into PP, a significant dependence of stress at rupture from aging was obtained, which increased by almost $19 \%$ compared to the initial value.

The elongation at rupture of the samples of the tested materials (Fig. 7) was slightly reduced compared to the unmodified PP, as expected. The largest decrease in elongation was observed in the case of sunflower husks introduced into 
polypropylene (61\%) and pine sawdust (58\%), slightly smaller with introduced talc and wheat bran $(45 \%)$. No statistically significant correlation between relative elongation at rupture and aging was obtained. However, there are slight tendencies in the decrease in elongation with the aging time, which is confirmed by the modulus of elasticity and aging dependency.

The results of the flammability tests carried out in the presence of an ignition source in the horizontal test of the unaged and aged modified polypropylene samples are given in Table 2, also providing the determined flammability class. The burning of the entire measuring section, dripping of burning drops and ignition of the cotton indicator were observed for all samples, both for before and after aging. The HB40 flammability class was obtained for all tested types of modified polypropylene, regardless of the type of filler and aging process. However, the introduced fillers changed the linear burning rate of polypropylene (Fig. 8). The highest rate of burning increased after the introduction of wheat bran (C), to $37.4 \mathrm{~mm} / \mathrm{min}$ with a value of $24.8 \mathrm{~mm} / \mathrm{min}$ obtained for pure PP. To a slightly smaller extent, the burning rate increased after the introduction of pine sawdust, by slightly more than $38 \%$ compared to pure PP, talc and sunflower husk (by 33.5 and 23.8\%, respectively).

The aging process did not affect the burning rate of pure PP and the talc-modified PP. The burning rate of the PP with the addition of

Table 2. Results of the horizontal flammability tests

\begin{tabular}{|c|c|c|c|c|}
\hline Type of filler & \multicolumn{2}{|c|}{ A } & \multicolumn{2}{|c|}{ B } \\
\hline Aging time $t_{s} \cdot h$ & 0 & 360 & 0 & 360 \\
\hline Burning time of the measuring section $t_{\mathrm{sp}} . \mathrm{s}$ & 182 & 179 & 147 & 140 \\
\hline The length of the burnt part $\mathrm{l}_{\mathrm{sp}} . \mathrm{mm}$ & 75 & 75 & 75 & 75 \\
\hline Linear burning speed $\mathrm{v}_{\mathrm{sp}} \cdot \mathrm{mm} / \mathrm{min}$ & 24.8 & 25.1 & 30.7 & 32.1 \\
\hline Flammability class in horizontal test & HB40 & HB40 & HB40 & HB40 \\
\hline Type of filler & \multicolumn{2}{|c|}{ C } & \multicolumn{2}{|c|}{ D } \\
\hline Aging time $t_{s} \cdot h$ & 0 & 360 & 0 & 360 \\
\hline Burning time of the measuring section $t_{s p} . s$ & 122 & 106 & 133 & 110 \\
\hline The length of the burnt part $\mathrm{I}_{\mathrm{sp}} \cdot \mathrm{mm}$ & 75 & 75 & 75 & 75 \\
\hline Linear burning speed $\mathrm{v}_{\mathrm{sp}} . \mathrm{mm} / \mathrm{min}$ & 37.4 & 42.5 & 34.3 & 40.9 \\
\hline Flammability class in horizontal test & HB40 & HB75 & HB40 & HB75 \\
\hline Type of filler & \multicolumn{2}{|c|}{ E } & & \\
\hline Aging time $t_{s} \cdot h$ & 0 & 360 & & \\
\hline Burning time of the measuring section $\mathrm{t}_{\mathrm{sp}} . \mathrm{s}$ & 136 & 140 & & \\
\hline The length of the burnt part $\mathrm{l}_{\mathrm{sp}} \cdot \mathrm{mm}$ & 75 & 75 & & \\
\hline Lineał burning speed $\mathrm{v}_{\mathrm{sp}} \cdot \mathrm{mm} / \mathrm{min}$ & 33.1 & 32.1 & & \\
\hline Flammability class in horizontal test & HB40 & HB40 & & \\
\hline
\end{tabular}

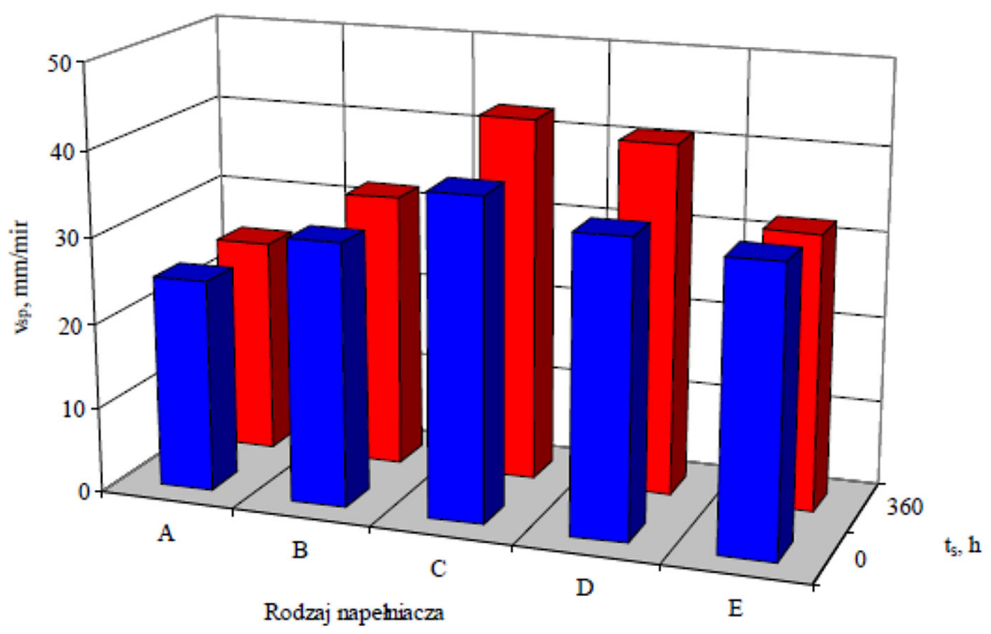

Fig. 8. Graph of the linear burning speed $v_{s p}$ on the filler type and aging time $t_{s}$ (designation in text) 
a)

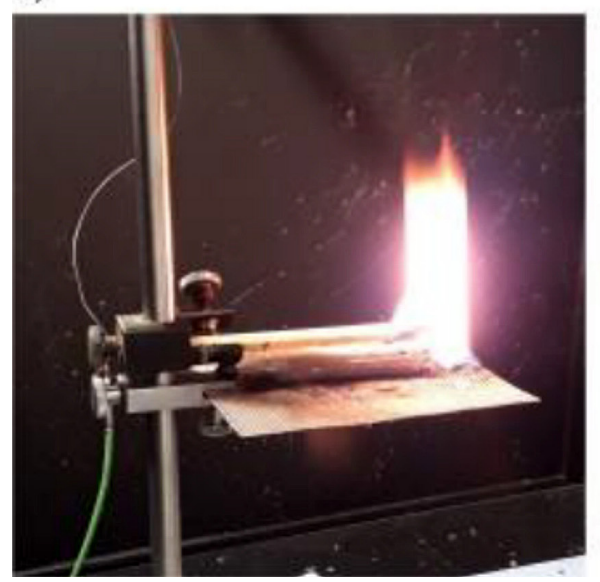

b)

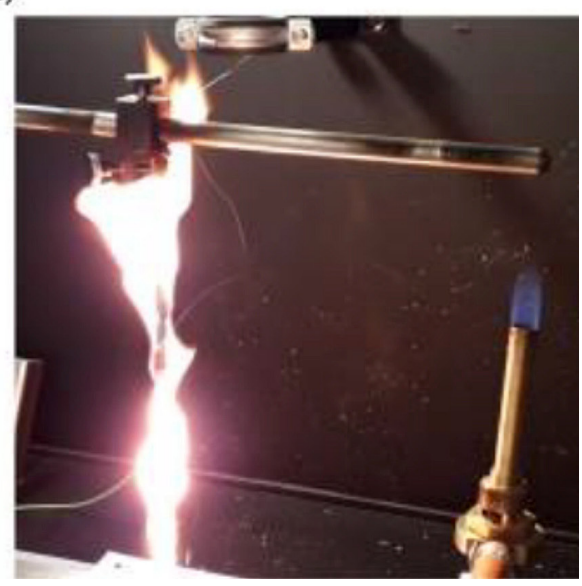

Fig. 9. Appearance of an exemplary polypropylene sample with $20 \%$ pine sawdust during the horizontal (a) and vertical (b) flammability testing

sunflower husk increased slightly (4.5\%) and to a slightly greater extent with the addition of wheat bran (13.6\%) and pine sawdust (19.2\%). A vertical flammability test was also carried out in accordance with the recommendations of PN-EN 60695-11-10. In all investigated cases, immediately after the ignition test (within 4-9 seconds) the flame covered the entire length of the sample (Fig. 9), which prevented both precise determination of the burning rate and determination of the flammability class.

\section{CONCLUSION}

As a result of the research, a significant impact of the introduction of natural fillers in the form of sunflower husks, wheat bran and pine sawdust on the selected properties of polypropylene was demonstrated. A large decrease in impact toughness, a relatively small decrease in short-term tensile strength and an increase in the elastic modulus and stress at rupture caused by the introduction of the natural fillers mentioned were found. There was also a clear decrease in relative elongation at maximum stress, which was in accordance with the expectations for the introduction of surfacemodified fillers. A beneficial effect was the relatively small impact of aging on the mechanical properties of the modified polypropylene fillers, which is a good prognosis regarding the lifetime of products made of this type of material. Only when stretching the polypropylene modified with pine chips was a decrease in strength caused by the aging process, which may be due to migration of resin compounds deteriorating their adhesion to polypropylene to the surface of this filler.

The same flammability class (BH40) of the PP samples tested was obtained for all the fillers introduced; however, a clear increase in the burning rate was observed, especially after the introduction of wheat bran and pine chips, which is an adverse effect. Obtaining better strength properties would be possible with the use of surface modification of the fillers used, which; however, would significantly increase the cost of manufacturing of products by both the injection and extrusion methods. However, even in non-structural construction products it would be purposeful to introduce flame retardants for this type of material. The added value in such materials is the attractive appearance and smell (transient) as well as accelerated degradation, especially in the case of thin-walled products, which, however, requires further research.

\section{REFERENCES}

1. Barton J. et al. Kompozyty, biokompozyty i nanokompozyty polimerowe. Otrzymywanie, skład, właściwości i kierunki zastosowań. Chemik, 4(68), 2014, 280-283.

2. Cynga R., Czaja K. Kompozyty polimerowe z napełniaczem roślinnym. Przemysł Chemiczny, 9(87), 2008, 932-936.

3. Dobrzyńska-Mizera M., Barczewski M. Wpływ dodatku napełniacza organicznego na właściwości mechaniczne kompozytów na osnowie polipropylenu. Przetwórstwo Tworzyw, 5(161), 2014, 399-404. 
4. Dulebova L., Garbacz T. The effect of particulate fillers on hardness of polymer composite. Advances in Science and Technology Research Journal, 3(11), 2017, 66-71.

5. Kijeński J., Błędzki A.K., Jeziórska R. Odzysk i recykling materiałów polimerowych. PWN, 2011.

6. Kijeński J., Kijeńska M., Osazuwa O. Włókna roślinne jako zamienniki włókien mineralnych w kompozytach termoplastów - wizja Forda czy Al Gore'a? Polimery, 7-8(61), 2016, 465-473.

7. Kuciel S. (ed.). Kompozyty polimerowe na osnowie recyklatów z włóknami naturalnymi. Wydawnictwo Politechniki Krakowskiej, 2010.

8. Ramaraj B., Poomalai P. Ecofriendly poly(vinyl alcohol) and coconut shell powder composite films: Physico-mechanical, thermal properties, and swelling studies. Journal of Applied Polymer Science, 102, 2006, 3862-3867.

9. Salasińska K., Ryszkowska J. The effect of filler chemical constitution and morphological properties on the mechanical properties of natural fiber composites. Composite Interfaces, 1(22), 2014, 39-50.

10. Samujło B. The methods of flame retarding of the thermoplastic composites and polymer mixtures. In: Sikora J.W., Suberlak O. (Eds.) Technological and design aspects of extrusion and injection moulding of thermoplastic polymer composites and nanocomposites. Lviv Polytechnic Publishing House, 2013.

11. Włodarczyk-Fligier A., Polok-Rubiniec M, Chmielnicki B. Kompozyty polimerowe z napełniaczem naturalnym. Przetwórstwo Tworzyw, 5(185), 2018, $50-57$. 